\title{
Retrospective Evaluation of Anaesthetic Techniques for Caesarean
}

\author{
Melek Aksoy Sar1 ${ }^{1}$, Semih Küçükgüçlü ${ }^{1}$, Şule Özbilgin ${ }^{1}$, Ferim Sakize Günenç ${ }^{1}$, Sümeyye Mercan², Ayşenur Esen², Büşra Yetim² \\ ${ }^{1}$ Department of Anaesthesiology and Reanimation, Dokuz Eylül University Faculty of Medicine, İzmir, Turkey \\ ${ }^{2}$ Faculty of Medicine Student, Dokuz Eylül University Faculty of Medicine, İzmir, Turkey
}

Objective: This study aimed to evaluate the maternal, foetal and neonatal effects of anaesthetic techniques used in caesarean sections (C/S) retrospectively over 6 years at the Hospital of Medical School of Dokuz Eylül University and to compare the results with the literature from Turkey and developed countries.

Methods: After obtaining approval from the ethics committee, anaesthetic and gestational data from all caesarean operations performed over a 6-year period between 2005 and 2010 was retrospectively obtained from hospital archives.

Results: During this period, a total of 10,819 labours was conducted and C/S ratio was 55\% with 5953 patients. General anaesthesia was performed in 1479 patients (24.8\%) and regional anaesthesia was performed in 4474 patients (75.2\%) [Spinal anaesthesia for 1203 patients (26.9\%), epidural anaesthesia for 830 patients (18.5\%) and combined spinal-epidural anaesthesia for 2441 patients (54.6\%)]. In 2010 , regional anaesthesia ratio increased to $84.6 \%$, whereas in 2005 , it was $63.8 \%$. Regional anaesthesia was used significantly more often in both elective and urgent patients ( $82 \%$ elective and $65.2 \%$ emergency). Because of failed regional anaesthesia or surgical complications, anaesthesia was changed to general anaesthesia in 215 patients (4.8\%). APGAR scores in 1 and 5 min were significantly higher with regional anaesthesia when compared with general anaesthesia.

Conclusion: Regional anaesthesia rate for C/S patients in the Hospital of Medical School of Dokuz Eylül University is increased and is higher than Turkey's average; but these figures are still lower than those in the developed countries.

Keywords: Caesarean section, anaesthesia, regional anaesthesia, retrospective study

\section{Introduction}

$\mathrm{T}$ he incidence of caesarean section $(\mathrm{C} / \mathrm{S})$, which is one of the most important interventions in obstetric surgery, is gradually increasing worldwide; however, it constitutes approximately $25 \%$ of all births in USA $(1,2)$.

The anaesthetic technique to be used in $\mathrm{C} / \mathrm{S}$ is determined according to some factors such as urgency, degree of $\mathrm{C} / \mathrm{S}$, presence of coexisting health problems, preference of patient and preference and experience of the anaesthetist and surgeon. Considering all these factors, the most appropriate general or regional anaesthetic technique is selected (1-5).

Regional anaesthesia (RA) is preferred because of high maternal mortality in general anaesthesia (GA) $(2,6)$. While $52 \%$ of anaesthesia-induced maternal mortality is associated with GA, 25\% occur during RA administration (7). However, according to the data between 1991 and 2002 in USA, a decrease was observed in anaesthesia-induced maternal mortality because of an increased use of RA in birth and C/S (1.2 death per 1,000,000 live births). Although mortality because of GA has decreased, this rate is increasing with an increased frequency of RA administration (8).

Mortality because of GA is often related to airway problems such as intubation failure, ventilation failure, aspiration pneumonia and oesophagus intubation; however, RA-induced mortality is related to excessively high neural block or toxicity of local anaesthetic drugs (1, 2, 7, 9-12). GA has an advantage of being a fast and safe technique in emergency cases with high bleeding risk. Moreover, airway and ventilation control can be performed with this method. In contrast, higher frequency of intubation and ventilation difficulty associated with physiological changes during pregnancy (such as bigger-sized breasts and oedema in the laryngopharyngeal regions), gastric fluid regurgitation and pulmonary aspiration risk, hypotension due to fast induction, airway complications in the early post-operative period, pain and nausea-vomiting are the disadvantages 
of GA. Other disadvantages include decreased Apgar scores of newborns because of the passage of intravenous anaesthetics through the placenta and haemodynamic and circulatory disorders that are associated with stress response to trauma in mothers using low-dose anaesthetic agents to prevent newborns from being affected by these agents $(1,4,5,10,11,13)$.

The contribution of regional anaesthesia to the establishment of a connection between the newborn and mother, because of mother's being a witness to the birth, should be taken into consideration. Other advantages of RA include causing less depression in foetus and enabling post-operative pain treatment $(1-4,14)$. In contrast, the most important disadvantages of RA are the possibility of developing hypotension and bradycardia, possibility of an insufficient analgesia level, it being a time-consuming procedure, it sometimes causing surgical difficulty because of not using muscle relaxants, headache depending on the technique, back pain, post-operative immobility, possible occurrence of urinary retention and development of allergy and toxicity because of local anaesthetics $(4,5,13)$.

In this study, the primary aim is to retrospectively evaluate maternal, foetal and neonatal effects of anaesthetic techniques used in $\mathrm{C} / \mathrm{S}$ surgeries. The secondary aim is to compare the obtained data with the literature of our country and developed countries.

\section{Methods}

After receiving ethical approval for this study from the Dokuz Eylül University Medical Faculty (Date: 20.01.2011 and No: 2011/02-28), the patient files that were registered in the central operating room and delivery room between 2005 and 2010 were examined.

The patients' age, height, weight, ASA physical classification, parity, number of babies, accompanying diseases to pregnancy, chronic diseases and caesarean indication were recorded; furthermore, duration of anaesthesia and surgery, time between the beginning of anaesthesia and beginning of surgery (min), newborn's Apgar scores at the $1^{\text {st }}$ and $5^{\text {th }}$ minutes, occurrence of stillbirth and maternal mortality and state of transfer to the intensive care unit were recorded.

While recording, the anaesthetic techniques used in $\mathrm{C} / \mathrm{S}$ were grouped as GA and RA. Moreover, RA was divided into subgroups as spinal anaesthesia (SA), epidural anaesthesia (EA) and combined spinal epidural anaesthesia (CSEA).

Data regarding GA; whether intubation difficulty was encountered or not and if encountered, what technique was used; unsuccessful RA trial; presence of previously inserted epidural catheter labour analgesia and whether it was switched from RA to GA or not were recorded.

The development of haemodynamic complications (hypotension, hypertension, bradycardia, tachycardia and arrhythmia) and the drugs administered for the development of complications (ephedrine, perlinganit and atropine) were evaluated. Hypotension was defined as systolic arterial pressure below $90 \mathrm{mmHg}$; hypertension was defined as systolic arterial pressure above $160 \mathrm{mmHg}$. Heart rate below 50 beats/min was defined as bradycardia, while that above 100 beats/min was considered as tachycardia. Arrhythmias observed beyond the sinus rhythm in the ECG were recorded.

\section{Statistical analysis}

For statistical analysis, the Statistical Package of Social Sciences 15.0 (SPSS Inc., Chicago, IL, USA) software was used. Chi-square test $\left(\chi^{2}\right)$ was used for comparisons between the groups. For numerical data, t-test and one-way ANOVA test were used. Of the data analysed using $\chi^{2}$ test, the number of patients was presented in figures (n) and percentage (\%) and numerical data were demonstrated as mean \pm standard deviation. The $\mathrm{p}$ value of $<0.05$ was accepted as statistically significant for all tests.

\section{Results}

A total of 10,819 deliveries were performed in the 6-year period. Of them, 4866 were vaginal births and 5953 were $\mathrm{C} / \mathrm{S}$. The number of babies that were born was 6332 . The demographic features of patients are given in Table 1. The distributions of anaesthesia administrations (Figure 1) and subgroups of RA (Figure 2 and Table 2) according to the years are presented below.

During this 6-year period, 3527 (59.2\%) elective C/S and 2426 (40.8\%) urgent C/S were performed. The use of RA was observed to be significantly high both in elective and emergency cases (82\% elective and $65.2 \%$ emergency; $(\mathrm{p}<0.001$; Table 2,3$)$. In contrast, the use of GA in emergency cases significantly decreased over the years $(\mathrm{p}<0.001$; Table 3). The subgroups of RA application according to the years are shown in Table 4.

Because RA failed in 18 patients, GA was administered. Epidural catheter was inserted in 397 patients for administering labour analgesia. When they were taken to the operating room for $\mathrm{C} / \mathrm{S}$, six patients were administered GA and six were administered SA despite the fact that the catheter had been inserted. In 215 cases (4.8\%), RA was switched to GA because of failure with RA and prolonged duration of intervention because of surgical complications. It was determined that $\mathrm{EA}$ was the most frequent $\mathrm{RA}$ technique that was switched to GA $(11.0 \%, \mathrm{n}=91 ; \mathrm{p}<0.001)$. While the rate of switching to GA was $5.7 \%(n=68)$ in $S A$, it was $2.3 \%$ $(n=56)$ in CSEA. Difficulty was encountered in four $(0.1 \%)$ of 1690 intubations but was performed without requiring another method.

Amongst all anaesthetic techniques, the incidence rate of hypertension was observed to be significantly higher in GA 


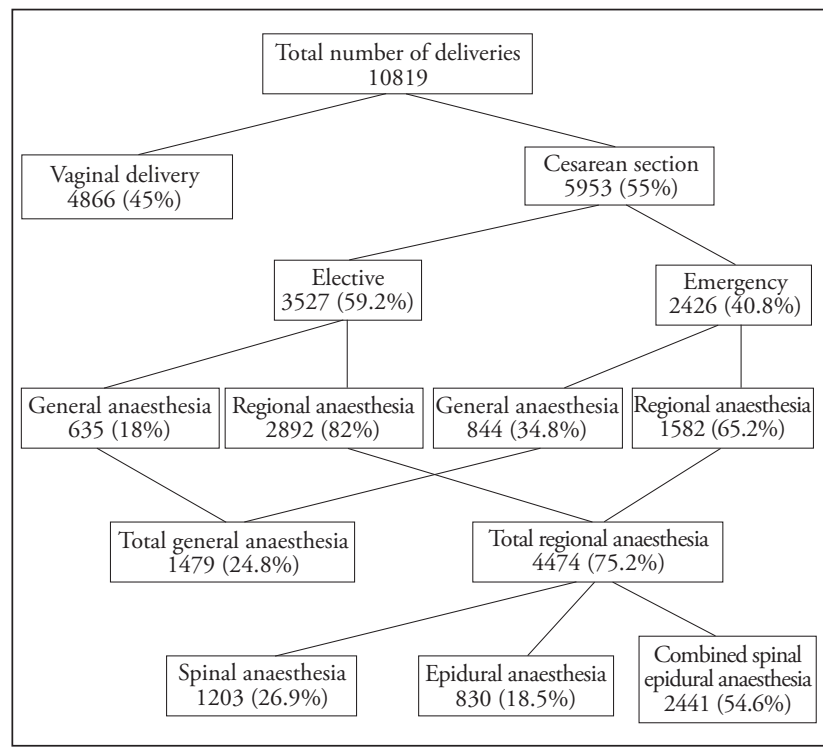

Figure 1. The total number of deliveries and the numbers and percentages of elective and emergency caesarean sections and the anaesthetic techniques that were used in the 6-year period.

$(\mathrm{p}<0.001)$. Haemodynamic complications and drugs used are shown in Table 5.

Nineteen patients were transported to the intensive care unit in the post-operative period because of surgical and haemodynamic complications. In one patient for each group of SA and CSEA, RA was switched to GA because of the occurrence of bleeding in association with placenta praevia, transfusion of red cells and fresh frozen plasma and haemodynamic instability.

A total of 6332 babies were born as a result of $5953 \mathrm{C} / \mathrm{S}$. Apgar scores both at the $1^{\text {st }}$ and $5^{\text {th }}$ minutes were observed to be significantly higher in RA than in GA $(\mathrm{p}<0.001)$. Moreover, in both techniques, the $5^{\text {th }}$-minute Apgar scores were significantly higher than the $1^{\text {st }}$-minute Apgar scores $(\mathrm{p}<0.001)$.

During the 6-year period, no pre-operative maternal mortality was observed in emergency and elective $\mathrm{C} / \mathrm{S}$ cases. The rate of stillbirth was calculated as $8 / 1000(n=45)$. No statistically significant difference was observed in the distribution of stillbirth rates over the years.

\section{Discussion}

It was detected that the frequency of RA administration gradually increased, and the rate was higher in Turkey but still lower in developed countries. At our hospital, the rate of $\mathrm{C} / \mathrm{S}$ was observed to be $55 \%$ in the 6-year period. The highest rate of $\mathrm{C} / \mathrm{S}$ was in 2010 (57.6\%), and the lowest rate of $\mathrm{C} / \mathrm{S}$ was in 2007 (52.7\%). These rates appear high compared with the rates of $\mathrm{C} / \mathrm{S}$ in Turkey and in the world. The rate of $\mathrm{C} / \mathrm{S}$ in our country was $21.2 \%$ according to the 2003 Population and Health Research but $36.7 \%$ in 2008 . According to the 2013 Turkish Ministry of Health, Health Statistics Reports, the rate of $\mathrm{C} / \mathrm{S}$ among all deliveries was $50.4 \%$ (15).The rate

Table 1. Demographic and obstetric data, indications for caeserean section, pregnancy-related and chronic diseases and durations

\begin{tabular}{|c|c|c|c|}
\hline & $\begin{array}{c}\text { GA } \\
(n=1479)(\%)\end{array}$ & $\begin{array}{c}\text { RA } \\
(n=4474)(\%)\end{array}$ & $\mathbf{p}$ \\
\hline Age (year) & $30.19( \pm 5.14)$ & $30.23( \pm 4.70)$ & 0.888 \\
\hline Height $(\mathrm{cm})$ & $163.00( \pm 5.85)$ & $164.02( \pm 6.18)$ & 0.026 \\
\hline Weight (kg) & $76.62( \pm 10.96)$ & $77.76( \pm 10.92)$ & 0.011 \\
\hline \multicolumn{4}{|l|}{ ASA } \\
\hline I & $21.5 \%(521)$ & $78.5 \%(1907)^{*}$ & $<0.001^{*}$ \\
\hline II & $26.7 \%(930)$ & $73.3 \%(2550)^{*}$ & $<0.001^{*}$ \\
\hline III & $62.2 \%(28)^{*}$ & $37.8 \%(17)$ & $<0.001^{*}$ \\
\hline \multicolumn{4}{|l|}{ Parity } \\
\hline 0 & $23.6 \%(754)$ & $76.4 \%(2441)^{*}$ & $<0.001^{*}$ \\
\hline 1 & $24.9 \%(555)$ & $75.1 \%(1672)^{*}$ & $<0.001^{*}$ \\
\hline 2 & $28.0 \%(119)$ & $72.0 \%(306)^{*}$ & $<0.001^{*}$ \\
\hline 3 & $48.1 \%(51)$ & $51.9 \%(55)^{*}$ & $<0.001^{*}$ \\
\hline \multicolumn{4}{|l|}{ Number of births } \\
\hline Single & $24.0 \%(1339)$ & $76.0 \%(4249)^{*}$ & $<0.001^{*}$ \\
\hline Multiple & $38.4 \%(140)$ & $61.6 \%(225)^{*}$ & $<0.001^{*}$ \\
\hline \multicolumn{4}{|l|}{ Indication for caesarean } \\
\hline Previous C/S & $23.5 \%(479)$ & $76.5 \%(1557)$ & 0.090 \\
\hline $\mathrm{CPD}$ & $16.5 \%(220)$ & $83.5 \%(1117)^{*}$ & $<0.001^{*}$ \\
\hline Foetal distress & $39.6 \%(390)$ & $60.4 \%(595)^{*}$ & $<0.001^{*}$ \\
\hline \multicolumn{4}{|l|}{ Pregnancy-related diseases } \\
\hline Gestational DM & $24.8 \%(134)$ & $75.2 \%(407)$ & 0.996 \\
\hline Preeclampsia & $35.2 \%(70)$ & $64.8 \%(129)^{*}$ & $0.001^{*}$ \\
\hline Thrombocytopenia & $67.9 \%(19)^{*}$ & $32.1 \%(9)$ & $<0.001^{*}$ \\
\hline Placenta previa & $57.4 \%(66)^{*}$ & $42.6 \%(49)$ & $<0.001^{*}$ \\
\hline Placenta acreta & $70.0 \%(7)^{*}$ & $30.0 \%(3)$ & $0.001^{*}$ \\
\hline Ablatio placenta & $75.7 \%(28)^{*}$ & $24.3 \%(29)$ & $<0.001^{*}$ \\
\hline \multicolumn{4}{|l|}{ Chronic diseases } \\
\hline Hypertension & $31.0 \%(13)$ & $69.0 \%(29)$ & 0.358 \\
\hline Diabetes mellitus & $24.1 \%(7)$ & $75.9 \%(22)$ & 0.930 \\
\hline $\begin{array}{l}\text { Respiratory system } \\
\text { disorder }\end{array}$ & $21.1 \%(12)$ & $78.9 \%(45)$ & 0.506 \\
\hline \multicolumn{4}{|l|}{ Duration } \\
\hline \multicolumn{4}{|c|}{ Duration of anaesthesia $(\mathrm{min}) 66.96( \pm 18.85) 70.80( \pm 17.42)<0.001^{*}$} \\
\hline Duration of surgery (min) & $56.85( \pm 17.85)$ & $53.35( \pm 15.40)$ & $<0.001^{*}$ \\
\hline $\begin{array}{l}\text { Time between anaesthesia } \\
\text { and surgery }(\mathrm{min})\end{array}$ & $2.30( \pm 2.27)$ & $17.03( \pm 6.23)$ & $<0.001^{*}$ \\
\hline $\begin{array}{l}{ }^{*} \mathrm{p}<0.05 \text { difference between anaesthet } \\
\text { Age, height, weight and durations are } \\
\text { are presented in } \% \text { ( } \mathrm{n}=\text { number of pat } \\
\text { numerical data, chi-square test in con } \\
\text { regional anaesthesia; min: minute; } \mathrm{C} /\end{array}$ & $\begin{array}{l}\text { etic techniques } \\
\text { e presented in mean } \pm \mathrm{s} \\
\text { tients). T-test and one-w } \\
\text { mparisons between grol } \\
\text { /S: caesarean section; } \mathrm{C}\end{array}$ & $\begin{array}{l}\text { standard deviation; oth } \\
\text {-way analysis of variance } \\
\text { oups. GA: general anaes } \\
\text { CPD: cephalopelvic dis }\end{array}$ & $\begin{array}{l}\text { her data } \\
\text { e test for } \\
\text { shesia; RA: } \\
\text { sproportion }\end{array}$ \\
\hline
\end{tabular}




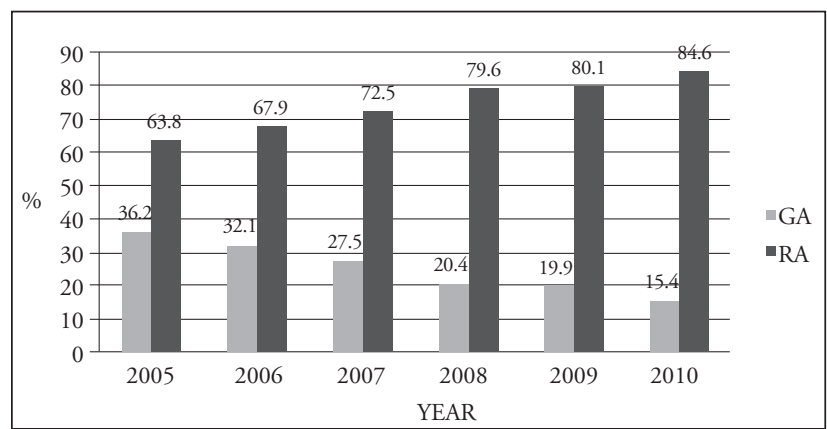

Figure 2. The distribution of anaesthetic techniques according to years GA: general anaesthesia; RA: regional anaesthesia

Table 2. The distributions and percentages of anaesthetic techniques used in elective caeserean sections according to years

\begin{tabular}{|ccccccccc|}
\hline & & $\mathbf{2 0 0 5}$ & $\mathbf{2 0 0 6}$ & $\mathbf{2 0 0 7}$ & $\mathbf{2 0 0 8}$ & $\mathbf{2 0 0 9}$ & $\mathbf{2 0 1 0}$ & Total \\
\hline GA & $\mathrm{n}$ & 141 & 94 & 123 & 110 & 107 & 60 & 635 \\
\cline { 2 - 9 } & $\%$ & 30.1 & 22.6 & 20.9 & 14.5 & 15.3 & 10.1 & 18.0 \\
\hline \multirow{2}{*}{ RA } & $\mathrm{n}$ & 327 & 322 & 466 & 649 & 592 & 536 & 2892 \\
\cline { 2 - 8 } & $\%$ & $69.9^{*}$ & $77.4^{*}$ & $79.1^{*}$ & $85.5^{*}$ & $84.7^{*}$ & $89.9^{*}$ & $82.0^{*}$ \\
\hline \multirow{2}{*}{ Total } & $\mathrm{n}$ & 468 & 416 & 589 & 759 & 699 & 596 & 3527 \\
\cline { 2 - 8 } & $\%$ & 100.0 & 100.0 & 100.0 & 100.0 & 100 & 100.0 & 100.0 \\
\hline${ }^{*} \mathrm{p}<0.001$, chi-square test. GA: general anaesthesia; RA: regional anaesthesia \\
\hline
\end{tabular}

Table 3. The distributions and percentages of anaesthetic techniques used in emergency caeserean sections according to years

\begin{tabular}{|ccccccccc|}
\hline & & $\mathbf{2 0 0 5}$ & $\mathbf{2 0 0 6}$ & $\mathbf{2 0 0 7}$ & $\mathbf{2 0 0 8}$ & $\mathbf{2 0 0 9}$ & $\mathbf{2 0 1 0}$ & Total \\
\hline GA & $\mathrm{n}$ & 189 & 190 & 155 & 119 & 99 & 92 & 844 \\
\cline { 2 - 9 } & $\%$ & 42.6 & 40.5 & 36.6 & $32.9 \%$ & 29.5 & 23.5 & 34.8 \\
\hline RA & $\mathrm{n}$ & 255 & 279 & 268 & 243 & 237 & 300 & 1582 \\
\cline { 2 - 8 } & $\%$ & $57.4^{*}$ & $59.5^{*}$ & $63.4^{*}$ & $67.1 \% \%^{*}$ & $70.5^{*}$ & $76.5^{*}$ & $65.2^{*}$ \\
\hline \multirow{2}{*}{ Total } & $\mathrm{n}$ & 444 & 469 & 423 & 362 & 336 & 392 & 2426 \\
\cline { 2 - 8 } & $\%$ & 100.0 & 100.0 & 100.0 & $\% 100.0$ & 100.0 & 100.0 & 100.0 \\
\hline${ }^{*} \mathrm{p}<0.001$, chi-square test. GA: general anaesthesia; RA: regional anaesthesia \\
\hline
\end{tabular}

Table 4. The distribution of the subgroups of regional anaesthesia according to years

\begin{tabular}{|lcccccccc|}
\hline & & $\mathbf{2 0 0 5}$ & $\mathbf{2 0 0 6}$ & $\mathbf{2 0 0 7}$ & $\mathbf{2 0 0 8}$ & $\mathbf{2 0 0 9}$ & $\mathbf{2 0 1 0}$ & Total \\
\hline SA & $\mathrm{n}$ & 26 & 88 & 183 & 125 & 360 & 421 & 1203 \\
\cline { 2 - 9 } & $\%$ & 4.5 & 14.6 & 24.9 & 14.0 & 43.4 & 50.4 & 26.9 \\
\hline \multirow{2}{*}{ EA } & $\mathrm{n}$ & 314 & 185 & 84 & 115 & 55 & 77 & 830 \\
\cline { 2 - 9 } & $\%$ & 54.0 & 30.8 & 11.4 & 12.9 & 6.6 & 9.2 & 18.5 \\
\hline CSEA & $\mathrm{n}$ & 242 & 328 & 467 & 652 & 414 & 338 & 2441 \\
\cline { 2 - 8 } & $\%$ & 41.6 & 54.6 & 63.6 & 73.1 & 49.9 & 40.4 & $54.6^{*}$ \\
\hline Total & $\mathrm{n}$ & 582 & 601 & 734 & 892 & 829 & 836 & 4474 \\
\cline { 2 - 8 } & $\%$ & 100.0 & 100.0 & 100.0 & 100.0 & 100.0 & 100.0 & 100.0 \\
\hline \multirow{2}{*}{$\begin{array}{l}\text { * }<<0.001, \text { chi-square test. SA: spinal anaesthesia; EA: epidural anaesthesia; } \text { CSEA: } \\
\text { combined spinal epidural anaesthesia }\end{array}$} \\
\hline
\end{tabular}

of $\mathrm{C} / \mathrm{S}$ that was as targeted by the World Health Organization with respect to maternal and perinatal mortalities was $15 \%$. In developed European countries, the rates varied between 16.6\% (Norway) and 37.4\% (Italy) as of 2008 (16).

In a study conducted in Turkey, which compared 4389 patients who underwent $\mathrm{C} / \mathrm{S}$, the rate of $\mathrm{C} / \mathrm{S}$ was detected as $43.72 \%$, and the rates of $\mathrm{C} / \mathrm{S}$ increased over the years (it was $37.7 \%$ in 2002 , while it was $51 \%$ in 2007) (17). In another study in which 20-year caesarean rates and indications were examined, the rates were observed to vary between $17.22 \%$ and $50.39 \%$ and the rates increased in the following years (18).

In a study performed in England, the rate of $\mathrm{C} / \mathrm{S}$, which was $12.7 \%$ in 1987 , increased to $24.2 \%$ in 2002 (19). It was reported that these rates ranged from $23.6 \%$ to $31.5 \%$ in USA (20). In Singapore, the rate of C/S was $25.2 \%$ (21). C/S was performed at the rate of $24 \%$ in Nigeria (6). In 2013, this rate was $32 \%$ in middle- and high-income European countries, whereas it was $16 \%$ in the rest of the world (15).

Large-scale retrospective and prospective studies have been planned for revealing the reasons for $\mathrm{C} / \mathrm{S}$ by the Mother and Child Care and Family Planning Centre under the Turkish Ministry of Health. It is believed that some factors including malpractice fear of physicians, inability to use painless birth (with EA) commonly, incompetent midwives for following and performing delivery actively and voluntary caesarean applications (accordingly, increased repeated $C / S$ ) and extended indications play a role in the elevation of these rates (16).

However, although drugs and materials used in anaesthetic techniques and developments in surgery and post-operative care have decreased caesarean-induced mortality and morbidity at present, the risks of infection, bleeding, transfusion need, thromboembolic disorders, longer hospitalisation, longer time for recovery and more pain still continue (16). Yalınkaya et al. (18) similarly reported previous caesarean, elective caesarean and foetal distress as the indications that increased at higher rate. In our study, the three most common caesarean indications were previous $\mathrm{C} / \mathrm{S}$ at the rate of $34.2 \%$, cephalopelvic disproportion (CPD) at the rate of $22.5 \%$ and foetal distress at the rate of $16.5 \%$.

The anaesthetic technique that will be used in $\mathrm{C} / \mathrm{S}$ is decided depending on several factors such as the urgency of caesarean, patient's existent systemic problems, patient's preference and preferences and experiences of the anaesthetist and surgeon. Considering all these factors, one of GA and RA techniques must be preferred according to their suitability (1-5).

RA is preferred mostly because of it being a safer technique for the mother and baby and because of a high level of maternal mortality in GA $(2,3,6)$. In addition, the use of RA in $\mathrm{C} / \mathrm{S}$ has increased over the years because of developed tools used in RA, increased knowledge and skills of anaesthetists 
Table 5. Haemodynamic complications and drugs that were used

\begin{tabular}{|c|c|c|c|c|c|}
\hline & $\begin{array}{c}\text { GA } \\
\%(\mathbf{n})\end{array}$ & $\begin{array}{c}\text { SA } \\
\%(n)\end{array}$ & $\begin{array}{c}\text { EA } \\
\%(\mathbf{n})\end{array}$ & $\begin{array}{l}\text { CSEA } \\
\%(n)\end{array}$ & $\begin{array}{l}\text { Total } \\
\% \text { (n) }\end{array}$ \\
\hline Hypotension & $1.4(21)$ & $29.8(359)$ & $26.4(219)$ & $38.5(941)^{*}$ & $25.9(1540)$ \\
\hline Ephedrine & $0.9(14)$ & $29.4(354)$ & 25.7 (213) & $37.3(911)^{*}$ & $25.1(1492)$ \\
\hline Hypertension & $8.0(118)^{*}$ & $1.6(19)$ & $0.8(7)$ & $0.8(20)$ & $2.8(164)$ \\
\hline Perlinganit & $0.9(13)^{*}$ & - & $0.1(1)$ & $0.1(3)$ & $0.3(17)$ \\
\hline Bradycardia & $1.8(27)$ & $4.0(48)$ & $4.1(34)$ & $6.3(155)^{*}$ & $4.4(264)$ \\
\hline Atropine & $1.8(26)$ & $4.0(48)$ & $4.0(33)$ & $6.2(152)^{*}$ & $4.3(258)$ \\
\hline Tachycardia & $16.6(245)^{*}$ & $5.2(62)$ & $6.9(57)$ & $4.3(106)$ & $7.9(470)$ \\
\hline Arythmia & $0.7(10)$ & $1.0(12)$ & $0.8(7)$ & $0.9(22)$ & $0.9(51)$ \\
\hline
\end{tabular}

in using these techniques and more conscious patients (4). However, the pace of this increase is not the same in all countries.

In the USA and European countries, the preference for RA techniques in $\mathrm{C} / \mathrm{S}$ is increasing $(1,2)$. Palanisamy et al. (20) evaluated GA administration in caesarean cases in a tertiary healthcare centre in the USA, and they observed that the rate of GA administration was between $0.5 \%$ and $1 \%$. In our country, GA is mostly preferred for C/S. Şahin et al. (22) reported the rate of RA in C/S as 29\% even in university hospitals, where the frequency rate of RA was the highest.

Töre et al. (23) observed that the rate of RA in C/S was $36.1 \%$ in their study. In addition, they detected that the rate of RA in university hospitals was 29\% in 1998 but increased to $50 \%$ in 2005 . In state hospitals, this rate increased from $10 \%$ to $30 \%$, and in private hospitals, it increased from $43 \%$ to $65 \%$. In the study by Kocamanoğlu et al. (4), it was revealed that the GA administration rate in $\mathrm{C} / \mathrm{S}$ was significantly higher than the total applications of RA, but the use of RA recently increased. In contrast, they stated that this rate was similar to that in Turkey, but was lower than that in developed countries. Toker et al. (3) observed that RA was applied at the rate of $77 \%$ in caesarean cases between 1996 and 2000, and the rate of SA administration was higher than the national average and similar to the rates of RA administrations in the western European countries.

In our study, the use of RA in C/S performed in the 6-year period was $75.2 \%$, which was different from the rate throughout the country but similar to the results of the study conducted by Toker et al. (3). Although the rate of CSEA use was detected to be the highest among all RA techniques, the most commonly used technique was EA in 2005 and SA in 2010.

In Nigeria, which is a developing country, $47.6 \%$ of $729 \mathrm{C} / \mathrm{S}$ were performed under GA, while $51.3 \%$ and $1.1 \%$ were performed with spinal SA and EA, respectively. The use of RA over the years was observed to be $18 \%$ in 2003 , $48 \%$ in 2004 ,
$72.6 \%$ in 2005 and $71 \%$ in 2006 . Based on these results, a tendency to use RA in $\mathrm{C} / \mathrm{S}$ was observed, which is consistent with our results (6).

At our hospital, $59.2 \%$ of cases $(n=3527)$ were elective and $40.8 \%(n=2426)$ were of emergency $\mathrm{C} / \mathrm{S}$ during the 6-year period. Compared with GA, the administration rate of RA was observed to be higher both in elective and emergency cases (82\% elective, $65.2 \%$ emergency). The use of RA in emergency $\mathrm{C} / \mathrm{S}$ cases gradually increased over years. It was $57.4 \%(n=255)$ in 2005 but $76.5 \%(n=300)$ in 2010 . In contrast, the use of GA in emergency cases decreased over years (it was $42.6 \%$ in 2005 , whereas it was $23.5 \%$ in 2010 ).

However, the rate of using RA in emergency cases in developed countries was $49.3 \%$ in 1992 and increased to $86.6 \%$ in 2002 (19). Moreover, another study reported the rate of RA administration in C/S as 77\% (24). The results of these studies show that the rates in our study are still low. In contrast, in the study conducted by Okafor et al. (6), 164 (40\%) of 410 emergency cases were administered SA and 3 were administered EA, which shows that our country is slightly ahead of developing countries.

In the study of Yildirım et al. (25), SA was administered in $14 \%$ urgent $\mathrm{C} / \mathrm{S}$ cases. The rate reported in our study is higher compared with these findings. In another study conducted on a special population with heart disease in 2014 , the rates of RA and GA techniques applied in the parturients were similar; however GA was preferred more commonly in the parturients having high New York Heart Association (NHYA) class, having undergone cardiac surgery and/or taking drug therapy. Researchers concluded that, in the anaesthesia management of parturients with heart diseases, criteria for GA could be narrowed and the use of EA or CSEA techniques could be increased depending on patient's clinical state, haemodynamic parameters and obstetric urgency (26). In addition, it can be suggested that the use of RA in emergency $\mathrm{C} / \mathrm{S}$ operations is increasing gradually in our country. Aksoy et al. (27) reported that $45 \%$ of total $9049 \mathrm{C} / \mathrm{S}$ were performed 
under GA and 54\% were performed under RA between the years of 2003 and 2012 and the rate of RA administration was $34 \%$ in 2003 but increased to $69 \%$ in 2012 . They observed that the most frequently used anaesthetic technique was SA in 2003 (34\%) and SA (41\%) and CSEA (27\%) in 2012. Günaydın et al. (28) reported that SA administration for elective $\mathrm{C} / \mathrm{S}$ and neuroaxial analgesia application for vaginal delivery increased in the last 7 years. In addition, they specified that this situation in Turkey was similar to that in many developing countries.

In our study, it was observed that RA was switched to GA in 215 patients $(4,8 \%)$ because of reasons such as prolonged duration of surgery associated with unsuccessful RA and surgical complications. The most common RA technique that was switched was EA $(11.0 \%, n=91)$. This rate was $5.7 \%(n=68)$ for SA and $2.3 \%(n=56)$ for CSEA. This result is consistent with the rate of $4 \%$ observed in the study by Palanisamy et al. (20). Kan et al. (21) conducted a retrospective study and reported that RA was switched to GA at the rate of $4 \%$ because of failure. They reported that the failure rate was higher in EA, which is consistent with our study. In another study performed in Singapore, RA was changed to GA at the rate of $1.7 \%$ because of epidural block failure (29). A study conducted in Kocaeli University revealed the rate of switching from SA to GA as 3.7\% (19 patients) because of insufficient block (3). These different failure rates can be related to changing definitions and variation of applied RA techniques.

GA was applied to $1479(24.8 \%)$ patients included in the study and difficulty was observed in $4(0.1 \%)$ of 1694 intubation procedures, but intubation was performed without requiring another technique. Whether oesophageal intubation and regurgitation were encountered or not could not be understood from the recordings. In contrast, in the study by Kan et al. (21), intubation difficulty was encountered in $4(0.5 \%)$ of 732 GA administrations. In a study examining the frequency of unsuccessful intubation and regurgitation in $\mathrm{C} / \mathrm{S}$ performed under GA in Pakistan, it was stated that no regurgitation and failed intubation was encountered in 2114 patients (30). Djabatey et al. (31) conducted a retrospective study on 3430 obstetric patients having undergone GA, and they observed that intubation difficulty was encountered in 23 cases, but no unsuccessful intubation and oesophageal intubation was performed in any case.

In our study, the time between the beginning of anaesthesia and the beginning of surgery was observed to be significantly higher in RA $(17.03 \pm 6.23 \mathrm{~min})$ than in GA $(2.30 \pm 2.27 \mathrm{~min})$. $\mathrm{McCahon}$ et al. (32) reported that the time spent for surgical preparation was $15.4 \pm 9.1 \mathrm{~min}$ for GA and $27.6 \pm 8.2 \mathrm{~min}$ for SA in their retrospective study they performed in 2003. However, the time between the beginning of anaesthesia and the beginning of surgery was not recorded in this study. Nonetheless, the time spent for SA was observed to be significantly higher compared with GA. In our study, although the time between the beginning of anaesthesia and the beginning of surgery was higher in RA than in GA, total anaesthesia times were close to each other in both groups $(66.96 \pm 18.85$ $\min$ for $G A, 70.80 \pm 17.42 \mathrm{~min}$ for $\mathrm{RA})$.

Umuroğlu et al. (33) compared SA with EA in their study, and they observed hypotension at the rate of $56 \%$ in SA and the dose of ephedrine was observed to be higher in SA. Kocamanoğlu et al. (4) did not specify the doses of drugs used in RA, but they reported that hypotension was mostly observed in SA $(28,6 \%)$ and no hypotension was encountered in CSEA applications.

In our study, the incidence of hypotension among all anaesthetic techniques was observed to be significantly higher in CSEA. Hypotension was observed in $29.8 \%$ SA administrations, in $26.4 \%$ EA administrations and in $38.5 \%$ CSEA administrations. The use of ephedrine in cases developing hypotension was revealed to be significantly higher in CSEA. The higher frequency of hypotension in CSEA can be attributed to our higher doses compared with the doses reported in literature. In the study of Küçükgüçlü et al. (34), in patients having undergone CSEA, hypotension developed within 5 min more frequently in isobaric bupivacaine group than in hyperbaric bupivacaine group and more need for ephedrine was observed. The incidence of hypertension among all anaesthetic techniques was observed to be significantly higher in GA, which is consistent with the study of Kocamanoğlu et al. (4). Hypertension developed in $8 \%$ cases that were administered GA.

In our study, both 1 st minute and $5^{\text {th }}$ min Apgar scores were significantly higher in RA than in GA, as in the studies of Yıldırım et al. (25) and Bowring et al. (24). Moreover, in both techniques, 5th minute Apgar scores were significantly higher than 1st min Apgar scores. However, in the study by Purtuloğlu et al. (5), in which they investigated the effects of GA and SA techniques on the mother and foetus in cases of elective $\mathrm{C} / \mathrm{S}$, no statistically significant difference was observed between the $1^{\text {st }}$ and $5^{\text {th }}$ min Apgar scores of the groups. In contrast, in the study conducted by Kayacan et al. (35), it was detected that only $1^{\text {st }}$ min Apgar scores were significantly lower in the GA group, but $5^{\text {th }}$ min Apgar scores were similar in the groups.

In our study, no maternal mortality developed in pre-operative period of emergency and elective $\mathrm{C} / \mathrm{S}$ cases during the 6 -year period. In contrast, Okafor et al. (6) encountered maternal mortality in a patient having undergone $\mathrm{C} / \mathrm{S}$ under GA, and they reported the cause of death to be intubation failure and pulmonary aspiration. Similarly, Kan et al. (21) reported one maternal mortality in C/S performed under GA and they stated that this was resulted from amniotic fluid embolism. Maternal bleeding is one of the most serious morbidity causes that make obstetric anaesthesia more difficult. The cause of maternal bleeding are placenta previa, abruptio placenta and uterus rupture (2). In our study, we observed 
placenta previa in 115 patients (1.9\%), placenta accreta in 10 patients $(0.2 \%)$ and ablatio placenta (abruptio placenta) in 37 patients $(0.6 \%)$. Blood and blood products were required in 42 patients $(0.7 \%)$, and GA was administered in $69 \%$ of them.

One of the limitations of the study is that RA-induced complications such as nausea-vomiting, itching, and post-dural puncture headache could not be evaluated because it was a retrospective study, as in the study of Toker et al. (3). It is a fact that lack of recordings and faulty records can be faced in such studies. Besides these, the role of patient in the choice of applied anaesthetic technique is unknown. Because the practitioner who applied the procedure in regional techniques (instructor, resident doctor, etc.) was not stated in anaesthesia records, the extent of experience-related failures could not be assessed in our study.

\section{Conclusion}

In recent years, the rate of $\mathrm{RA}$ administration in $\mathrm{C} / \mathrm{S}$ is gradually increasing, and the RA technique that is mostly preferred is CSEA because it facilitates the administration of an additional dose in the case of prolonged surgery and post-operative analgesia. Furthermore, we suggest that the records should be kept in more detailed and systematic way or transferred to electronic environment to obtain reliable results in retrospective studies.

Ethics Committee Approval: Ethics committee approval was received for this study from the ethics committee of Dokuz Eylül University Faculty of Medicine (20.01.2011, 2011/02-28).

Informed Consent: Due to the retrospective nature of the study, informed consent was waived.

Peer-review: Externally peer-reviewed.

Author Contributions: Concept - S.K.; Design - S.K., M.A.S., Ş.Ö., S.F.G.; Supervision - SK.; Funding - S.K., M.A.S.; Materials - M.A.S., S.M., A.E., B.Y.; Data Collection and/or Processing - F.S.G., S.M., A.E., B.Y.; Analysis and/or Interpretation - S.K., F.S.G., Ş.Ö.; Literature Review - M.A.S., Ş.Ö., S.F.G.; Writer M.A.S.; Critical Review - S.K.; Other - F.S.G., Ş.Ö.

Conflict of Interest: No conflict of interest was declared by the authors.

Financial Disclosure: The authors declared that this study has received no financial support.

\section{References}

1. Birnbach DJ, Browne IM. Anesthesia for obstetrics. In: Miller's Anesthesia. Miller RD (ed). 7.Edition. New York: Churchill Livingstone; 2009: 2203-40.

2. Morgan GE, Mikhail MS, Murray MJ. Obstetrik anestezi, Clinical Anaesthesiology. Klinik Anesteziyoloji. Çev. Edt: Tulunay M, Cuhruk H. 4. Baskı. Öncü basımevi, Ankara; 2008: 890921.
3. Toker K, Yılmaz AS, Gürkan Y, Baykara N, Canatay H, Özdamar D, et al. Anesthesia for Caesarean surgery, 5-year retrospective evaluation. Sezaryen ameliyatlarında anestezi uygulaması, 5 yıllık retrospektif değerlendirme. TARCM 2003; 31: 26-30.

4. Kocamanoğlu İS, Sarıhasan B, Şener B, Tür A, Şahinoğlu H, Sunter T. Sezaryen operasyonlarında uygulanan anestezi yöntemleri ve komplikasyonları: 3552 olgunun retrospektif değerlendirilmesi. Turkiye Klinikleri J Med Sci 2005; 25: 810-6.

5. Purtuloğlu T, Özkan S, Teksöz E, Dere K, Şen H, Yen T, ve ark. Elektif sezaryen uygulanan olgularda genel ve spinal anestezinin maternal ve fetal etkilerinin karşılaştırılması. Comparison of maternal and fetal effects of general and spinal anesthesia in patients undergoing elective cesarean section. Gülhane Tip Dergisi 2008; 50: 91-7.

6. Okafor UV, Ezegwui HU, Ekwazi K. Trends of different forms of anaesthesia for caesarean section in South- eastern Nigeria. J Obstet Gynaecol 2009; 29: 392-5. [CrossRef]

7. Ross BK. ASA closed claims in obstetrics: lessons learned. Anesthesiol Clin North Am 2003; 21: 183-97. [CrossRef]

8. Hawkins JL, Chang J, Palmer SK, Gibbs CP, Callaghan WM. Anesthesia-related maternal mortality in United States: 19792002. Obstet Gynecol 2011; 117: 69-74. [CrossRef]

9. Tsen LC. General versus regional anesthesia for emergency cesarean delivery. In: The Sol Shnider, Obstetrical Anesthesia Meeting, San Francisco. Obstetrical Anesthesia 2007: 3-33.

10. Munnur U, Boisblanc B, Suresh MS. Airway problems in pregnancy. Crit Care Med 2005; 33: 259-68. [CrossRef]

11. Davies NJH, Cashman JN. Çev; Turan IÖ. Obstetri, Lee’s Synopsis of Anaesthesia. Güneş kitapevleri 2008: 657-80.

12. Hawkins JL. Anesthesia-related maternal mortality. Clin Obstet Gynecol 2003; 46: 679-87. [CrossRef]

13. Dresner MR, Freeman JM. Anaesthesia for caesarean section. Best Pract Res Clin Obstet Gynaecol 2001; 15: 127-43. [CrossRef]

14. Tekin İ, Laçin S, Arıcan İ, Ok G. Sezaryen operasyonu geçirmiş olguların "anestezi yöntemi” nin seçimi üzerine etkileri. Of patients who had cesarean operation "anesthesia technique" effects on the choice. Turkiye Klinikleri J Anest Reanim 2005; 3: 1-6.

15. T.C. Sağlık Bakanlığı Sağlık İstatistikleri Yıllığı 2013, Ankara. T. C. Ministry of Health Statistics Yearbook 2013, Ankara, Turkey. Edt. Başara BB, Gökalp CG, Yentür K. Sentez Matbaacılık ve Yayıncılık Tic. Ltd. Şti. Ankara; 2013: 60.

16. Doğum ve sezaryen eylemi yönetim rehberi. T.C. Sağlık Bakanlığı Ana Çocuk Sağlığı ve Aile Planlaması Genel Müdürlüğü Ankara, 2010. Cesarean birth and action management guide. T. C. Ministry of Health Maternal and Child Health and Family Planning General Directorate Ankara 2010, Turkey. Damla Matbaacılık, Reklamcılık ve Yayıncılık Tic. Ltd. Şti. Ankara; 2010: 7.

17. Yılmaz M, İsaoğlu Ü, Kadanalı S. Kliniğimizde 2002-2007 yılları arasında sezaryen olan hastaların incelenmesi. Investigation of patients with cesarean section in our clinic between 2002 and 2007. Marmara Medical Journal 2009; 22: 104-10.

18. Yalınkaya A, Bayhan G, Kale A, Yayla M. Dicle Üniversitesinde 20 yıllık sezaryen oranı ve endikasyonları. 20 years and indications for cesarean rate at Dicle University. T Klin Jinekol Obst 2003; 13: 356-60.

19. Jenkins JG, Khan MM. Anaesthesia for caesarean section: a survey in a UK region from 1992 to 2002. Anaesthesia 2003; 58: 1114-8. [CrossRef] 
20. Palanisamy A, Mitani AA, Tsen LC. General anesthesia for cesarean delivery at a tertiary care hospital from 2000 to 2005: a retrospective analysis and 10-year update. Int J Obstet Anesth 2011; 20: 10-6. [CrossRef]

21. Kan RK, Lew E, Yeo SW, Thomas E. General anesthesia for cesarean section in a Singapore maternity hospital: a retrospective survey. Int J Obstet Anesth 2004; 13: 221-6. [CrossRef]

22. Şahin Ş, Owen M. Türkiye'de ve dünyada obstetrik analjezi ve anestezi. Obstetric analgesia and anesthesia in the world and Turkey. TARCM 2002; 30: 52-9.

23. Töre G, Gurbet A, Şahin Ş, Türker G, Yavaşcaoğlu B, Korkmaz S. Türkiye'de obstetrik anestezi uygulamalarındaki değişimin değerlendirilmesi. Evaluation of changes in obstetric anesthesia in Turkey. Turk J Anaesth Reanim 2009; 37: 86-95.

24. Bowring J, Franser N, Vause S, Heazell AEP. Is regional anaesthesia beter than general anaesthesia for caesarean section? J Obstet Gynaecol 2006; 26: 433-4. [CrossRef]

25. Yıldırım GB, Çolakoğlu S, Bombacı E, Gül S. Acil kadın hastalıkları ve doğum ameliyatlarında anestezi uygulamalarımız. Our anesthesia practice in emergency obstetrics and gynecology surgery. Van Tip Dergisi 2006; 13: 56-60.

26. Yıldırım Ö, Günüşen İ, Sargın A, Fırat V, Karaman S. The evaluation of applied anaesthetic techniques for caesarean in parturients with cardiac diseases: retrospective analysis. Turk J Anaesth Reanim 2014; 42: 326-31. [CrossRef]

27. Aksoy M, Aksoy AN, Dostbil A, Gürsaç ÇM, Ahıskalığlu A. Anaesthesia techniques for caesarean operations: retrospective analysis of last decade. Turk J Anaesth Reanim 2014; 42: 128-32. [CrossRef]
28. Günaydın B, Kaya K. A retrospective seven years audit of mode of deliveries in a tertiary care university hospital of Turkey. Anaesth Pain Intensive Care 2013; 17: 51-4.

29. Lee S, Lew E, Lim Y, Sia AT. Failure of augmentation of labor epidural analgesia for intrapartum cesarean delivery: a retrospective review. Anesth Analg 2009; 108: 252-4. [CrossRef]

30. Ajmal M. General anaesthesia for caesarean sections: are anaesthetists dealing with exaggerated fear? Eur J Anaesthesiol 2011; 28: 815-6. [CrossRef]

31. Djabatey EA, Barclay PM. Difficult and failed intubation in 3430 obstetric general anaesthetics. Anaesthesia 2009; 64: 1168-71. [CrossRef]

32. McCahon RA, Catling S. Time required for surgical readiness in emergency caesarean section: spinal compared with general anaesthesia. Int J Obstet Anesth 2003; 12: 178-82. [CrossRef]

33. Umuroğlu T, Yaycı A, Eti Z, Göğüş FY. Sezaryen operasyonlarında bölgesel anestezi yöntemi seçimi. Choice of regional anesthesia in cesarean section. Turkiye Klinikleri J Anest Reanim 2006; 4: 80-3.

34. Kucukguclu S, Unlugenc H, Gunenc F, Kuvaki B, Gokmen N, Gunasti S, et al. The influence of epidural volume extension on spinal blok with hyperbaric or plain bupivacaine for caesarean delivery. Eur J Anaesthesiol 2008; 25: 307-13. [CrossRef]

35. Kayacan N, Bigat Z, Yeğin A, Karslı B, Akar M. A randomized prospective study on the maternal and neonatal outcome of epidural, combined spinalepidural and general anesthesia for elective caesarean sections. Turkiye Klinikleri J Med Sci 2004; 24: 476-82. 